\title{
Efficacy of Minocycline in Neural Stem Cells Proliferation after Traumatic Brain Injury
}

\author{
R. R. Suzy Indharty*, Iskandar Japardi, Andre M. P. Siahaan, Steven Tandean, Michael Lumintang Loe \\ Department of Neurosurgery, School of Medicine, Universitas Sumatera Utara, Haji Adam Malik General Hospital, Medan, \\ Indonesia
}

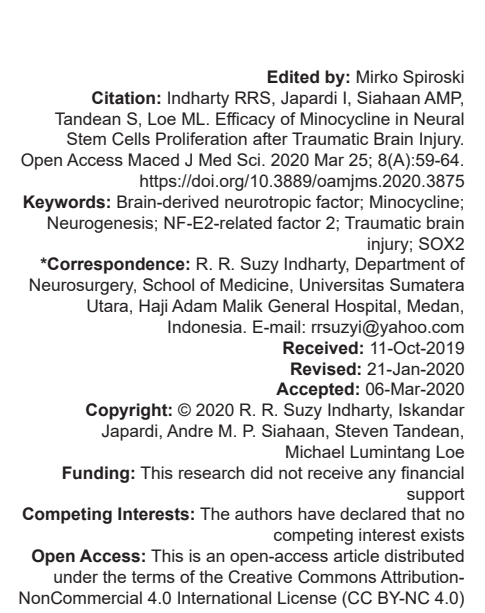

Abstract

BACKGROUND: Neuroinflammation is an important secondary injury mechanism that contributes to neurological impairments after traumatic brain injury (TBI). There is a robust evidence that neuroinflammation will diminish neurogenesis after TBI. Therefore, strategies to attenuate the inflammatory responses are potential to increase neurogenesis following TBI. Minocycline, a second-generation tetracycline antibiotic derivate, has potent antiinflammatory effect by reducing microglial activation and suppressing some pro-inflammatory cytokines.

AIM: The aim of this study is to investigate if minocycline could enhance neurogenesis after TBI.

METHODS: Thirty Sprague Dawley rats were randomized into three treatments group, i.e., sham-operated controls, closed head injury (CHI), and $\mathrm{CHI}$ with minocycline. We used the modified Feeney's weight-drop model for making $\mathrm{CHI}$. For the treatment group, we gave minocycline per oral $(50 \mathrm{mg} / \mathrm{kg})$ twice daily for the first 2 days followed by $25 \mathrm{mg} /$ $\mathrm{kg}$ once daily for 3 consecutive days. Animals were sacrificed on day 5 . To assess the proliferation capacity of neural stem cells (NSC), we performed immunohistochemistry staining with SOX2, brain-derived neurotropic factor (BDNF), and NFR. Cell counts were carried out using light microscope with 1000 times magnification in 20 high-power fields.

RESULTS: SOX2, NF-E2-related factor 2 (NRF-2), and BDNF were upregulated in the $\mathrm{CHI}$ group compared to the sham-operated group $(p<0.05)$. NRF-2, BDNF, and SOX2 were upregulated also significantly in the $\mathrm{CHI}+$ minocycline group compared to the sham-operated group and the $\mathrm{CHI}$ group $(p<0.05)$.

CONCLUSION: Minocycline increased the proliferation capacity of NSC.

\section{Introduction}

Neurogenesis is the process of developing new neural cells from multipotent cells. Formerly, this process was believed to happen only during embryonic development. At present, it is generally accepted that neurogenesis can also happen in the adult brain, i.e., in the subgranular zone (SGZ) in the dentate gyrus (DG) of the hippocampus, as well as the subventricular zone lining the lateral ventricles. Neural stem cells (NSCs) are the multipotent cells that will proliferate and migrate to the granule cell layer in the DG. In DG, the NSCs will differentiate into neurons, astrocytes, or oligodendrocytes. The neurons then project into the hippocampus and become fully functional, integrated into the brain circuit [1], [2]. The neurogenesis process itself depends on a complicated microenvironment that requires multiple signaling between multiple cell types [3].

Traumatic brain injury (TBI) remains one of the most prominent causes of mortality and morbidity, especially in the young population [4]. TBI itself is a complex process, not just a single pathophysiological event [5]. The initial primary injury was followed by secondary injury that involves various pathways, including profound cerebral inflammation, excitatory amino acids and calcium associated cytotoxicity, and ischemic events. These injuries are seen as the cause of the development of neurological deficits after TBI [6].

Neuroinflammation is an important secondary injury mechanism that contributes to ongoing neurodegeneration and neurological impairments after TBI. Post-traumatic neuroinflammation is characterized by microglial activation, leukocyte recruitment, and upregulation of inflammatory mediators [7]. Neuroinflammation can play dual opposing roles. On the one hand, neuroinflammation will support repair and regeneration processes. On the other hand, it could exacerbate tissue damage. Microglial activation associated with neural inflammation diminishes neurogenesis in the hippocampus [8]. Interleukin 6, one of the inflammatory mediators, decreases the neurogenesis by more than half in the DG. Prolonged mitochondrial dysfunction was correlated with long-term diseases, such as Alzheimer's disease [9]. Therefore, strategies to mitigate the inflammatory responses are potential to decrease neuron death and increase neurogenesis following TBI [10]. 
Minocycline is a second-generation tetracycline antibiotic derivate that can cross the blood-brain barrier [11]. It is very crucial since the blood-brain barrier prevents the most type of chemicals from moving from the bloodstream into the central nervous system (CNS) [12]. Minocycline has been used in numerous neurological disorders, such as spinal cord injury [13], [14], ischemic brain injury [15], [16], Parkinson [17], and TBI [14], [18], [19]. Even the mechanism of neuroprotective effect of minocycline has not been fully elucidated, one of the most proposed mechanisms is an anti-inflammatory effect. Minocycline has potent anti-inflammatory effect by reducing microglial activation [20], [21], [22] and suppressing the generation of some pro-inflammatory cytokines [21], [23], [24].

\section{Methods}

\section{Mouse model of closed head injury (CHI)}

Thirty Sprague Dawley rats weighing 250-400 g were randomized into three treatment groups, i.e., sham-operated controls, $\mathrm{CHI}$, and $\mathrm{CH}$ with minocycline ( $\mathrm{CHI}+$ minocycline). All animals were given ketamine $\mathrm{HCl}(100 \mathrm{mg} / \mathrm{kg}$, intramuscular) as an anesthetic agent. The scalp was cleaned with povidone-iodine and aseptic techniques were utilized throughout the surgery. The scalp was opened on the right frontal. Then, the rats were placed securely in stereotactic apparatus. We used modified Feeney's drop model protocol to induce brain injury (20). A $40 \mathrm{mg}$ metal mass was dropped from a height of $1.5 \mathrm{~m}$, onto the right side of the head (Figure 1a). The brains were then removed (Figure $1 \mathrm{~b}$ ) and fixed in $10 \%$ formalin. The specimens were subsequently processed for paraffin embedded for immunohistochemistry staining. Sham-operated mice underwent anesthesia and surgery, without trauma and treatment.

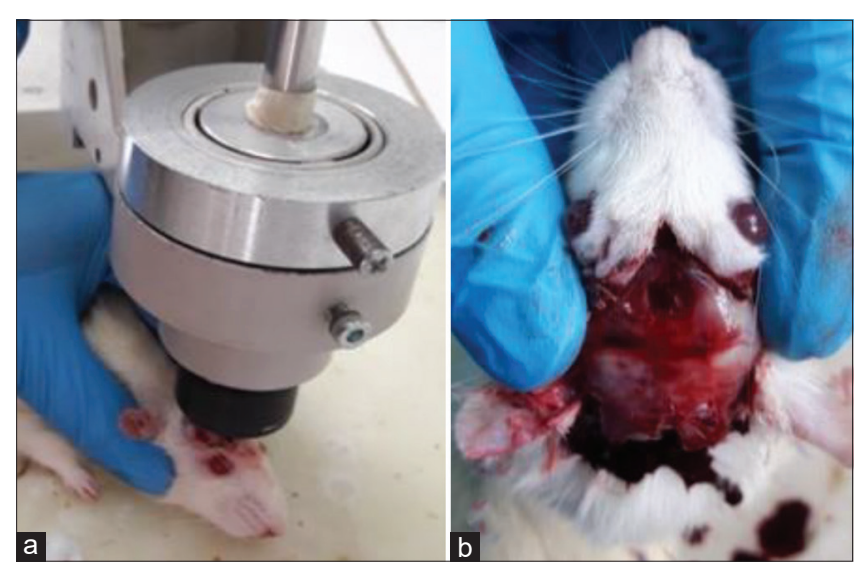

Figure 1: Animal model. (a) Weight drop after craniotomy. (b) Brain removal after craniocervical dislocation

\section{Minocycline treatment protocol}

Mice were given minocycline per oral $50 \mathrm{mg} / \mathrm{kg}$ daily for the $1^{\text {st }}$ day followed by $25 \mathrm{mg} / \mathrm{kg}$ once daily for consecutive 4 days (5 days total) [8].

\section{Immunohistochemistry staining}

As a neurogenesis marker, we investigated the expression of the sex-determining region of the $Y$ chromosome (Sry)-related high mobility group box2 (SOX2 antibody (E-4): sc-365823; St. Cruz), NF-E2-related factor 2 (NRF2 antibody [A-10]: sc-365949; St. Cruz), and mature brain-derived neurotropic factor (BDNF) (BDNF antibody [N-20]: sc-546; St. Cruz). The expression of all markers was investigated on paraffin-embedded sections using the avidin-biotin-peroxidase complex method. Five millimeters thick paraffin sections were dewaxed, rehydrated, and microwaved for $10 \mathrm{~min}$. The endogenous peroxidase activity of the investigated specimens was blocked with $3 \% \mathrm{H}_{2} \mathrm{O}_{2}$ for $10 \mathrm{~min}$, followed by $25 \mathrm{~min}$ of washing with phosphate-buffered saline (PBS).
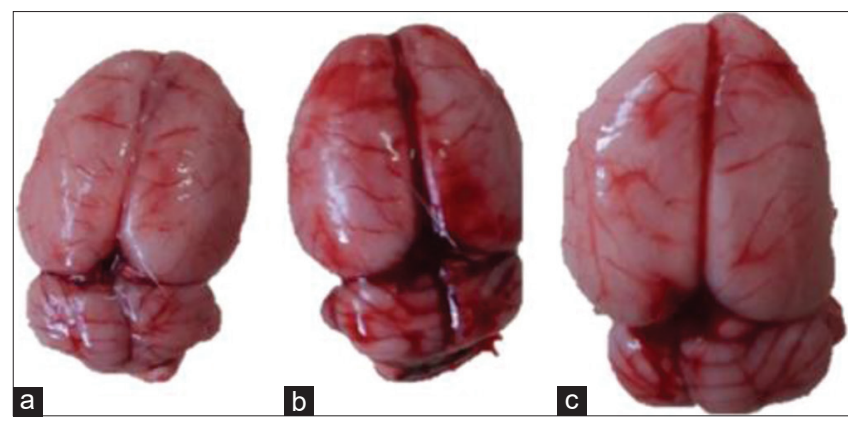

Figure 2: Mice brain after removal. (a) Closed head injury (CHI) group. (b) Negative sham group. (c) CHI+minocycline group

The tissue sections were incubated with normal rabbit serum for $10 \mathrm{~min}$, and then, the slides were incubated at room temperature with monoclonal mouse anti-human SOX2, NRF, andBDNF (Santa Cruz). Sectionswerewashed with PBS and incubated with a secondary antibody for 30 min. Sections were washed twice with PBS, developed with $0.05 \%$ 3,3-diamino-benzinetetrahydrochloride for 5 min, and slightly counterstained.

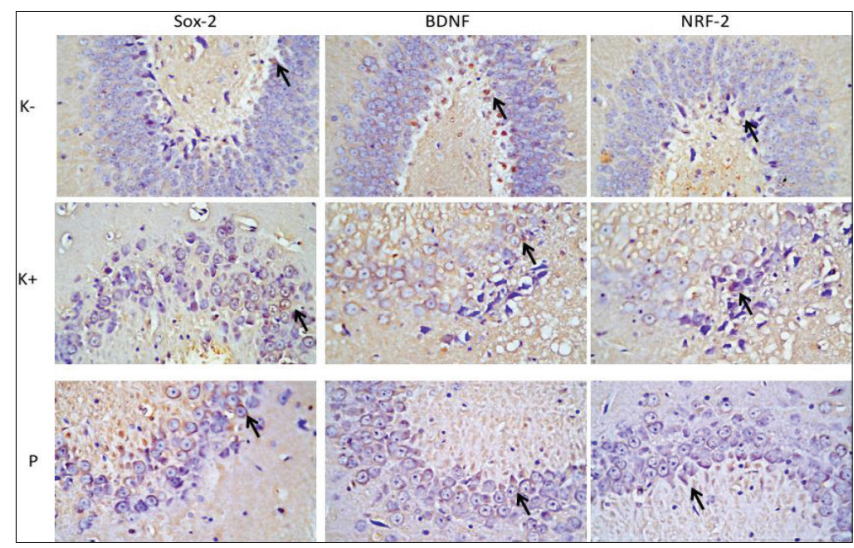

Figure 3: Expression of SOX2, brain-derived neurotropic factor, and NF-E2-related factor 2 in every group of brain tissues 5 days after closed head injury 
All samples were evaluated by one pathologist (blinded) and first author (not blinded to specimen). Positive signal for SOX2, NRF, and BDNF was located in the nucleus of brain cells and the stainability was quantitatively estimated on the basis of the distribution of positively stained cells in the DG. Cell counts were carried out using a light microscope with 1000 times magnification in 20 high-power fields.

\section{Statistical analysis}

Total stained cells were reported as mean and standard deviation. When comparisons were made between groups, significance between-group variability was analyzed using the one-way ANOVA test with Tukey as post hoc test with JASP vers. 0.8.4. Differences were considered statistically significant at $p<0.05$.

\section{Results}

Thirty rats were included in this research, divided into three groups, i.e., sham-operated controls, $\mathrm{CHI}$, and $\mathrm{CHI}+$ minocycline. Minocycline was given consecutively in 5 days. During the follow-up, two rats died directly after trauma procedure. The brain was removed after craniocervical dislocation (Figure 2).

\section{SOX2, NRF-2, and BDNF were upregulated}

\section{in $\mathrm{TBI}$}

Immunohistochemistry was used to detect the expression of SOX2, NRF-2, and BDNF in brain tissue 5 days after $\mathrm{CH}$. As expected, SOX2, NRF2 , and BDNF were localized to the nucleus. All of the immunopositive cells were found to be present in the DG, as well as generally in the brain parenchyma (Figure 3). Immunopositive cells to SOX2 in shamoperated controls were $2.44 \pm 1.01$. Meanwhile, it was $8.56 \pm 1.24$ in the $\mathrm{CHI}$ group. Immunopositive cells to NRF-2 in sham-operated controls and $\mathrm{CHI}$ were 3.33 \pm 1.22 and $9.89 \pm 2.26$, respectively. Immunopositive cells to BDNF in sham-operated controls were $7.33 \pm$ 1.23 and in $\mathrm{CHI}$ were $9.78 \pm 1.56$. We found that SOX2, NRF-2, and BDNF were significantly upregulated in the $\mathrm{CHI}$ group compared to the sham-operated group $(p<$ 0.05; Table 1).

Table 1: Expression of SOX2, NRF-2, and $\mathrm{m}-\mathrm{BDNF}$ in negative sham, $\mathrm{CHI}$, and $\mathrm{CHI}+$ minocycline groups

\begin{tabular}{llll}
\hline Group & SOX2 & NRF & BDNF \\
\hline Negative sham & $2.44 \pm 1.01$ & $3.33 \pm 1.22$ & $7.33 \pm 1.23$ \\
$\mathrm{CHI}$ & $8.56 \pm 1.24$ & $9.89 \pm 2.26$ & $9.78 \pm 1.56$ \\
$\mathrm{CHI}+$ minocycline & $11.67 \pm 1.94$ & $12.67 \pm 1.80$ & $12.00 \pm 1.22$ \\
$\mathrm{p}$ & 0.0001 & 0.0001 & 0.0001 \\
\hline One-way ANOVA; & *significant. CHI: Closed head injury, NRF-2: NF-E2-related factor 2, m-BDNF: m-brain- \\
derived neurotropic factor.
\end{tabular}

Minocycline modulated the expression of transcription factor NRF-2

After the systemic administration of minocycline, it showed that minocycline modulated the expression of transcription factor NRF-2. The mean of immunopositive cells to NRF-2 was $12.67 \pm 1.80$ (Figure 4). Immunohistochemistry showed that NRF-2 was significantly upregulated in the $\mathrm{CHI}+$ minocycline group compared to the sham-operated group and the CHI group $(p<0.05$; Table 1$)$.

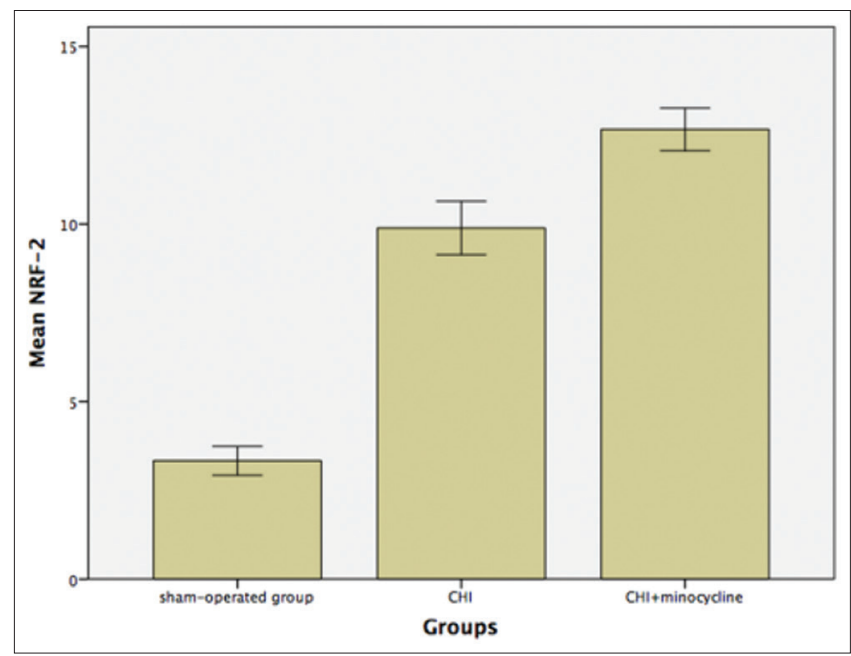

Figure 4: Expression of NF-E2-related factor 2 in brain tissue 5 days after

\section{$B D N F$}

Minocycline upregulated the expression of

After the systemicadministration of minocycline, it was shown that minocycline also modulated the expression of BDNF. Mean of immunopositive cells to BDNF was $12.00 \pm 1.22$ (Figure 5). We found that the number of cells labeled with BDNF was significantly increased in the $\mathrm{CHI}+$ minocycline group compared to the sham-operated group as well as the $\mathrm{CHI}$ group $(p<0.05$, Table 1).

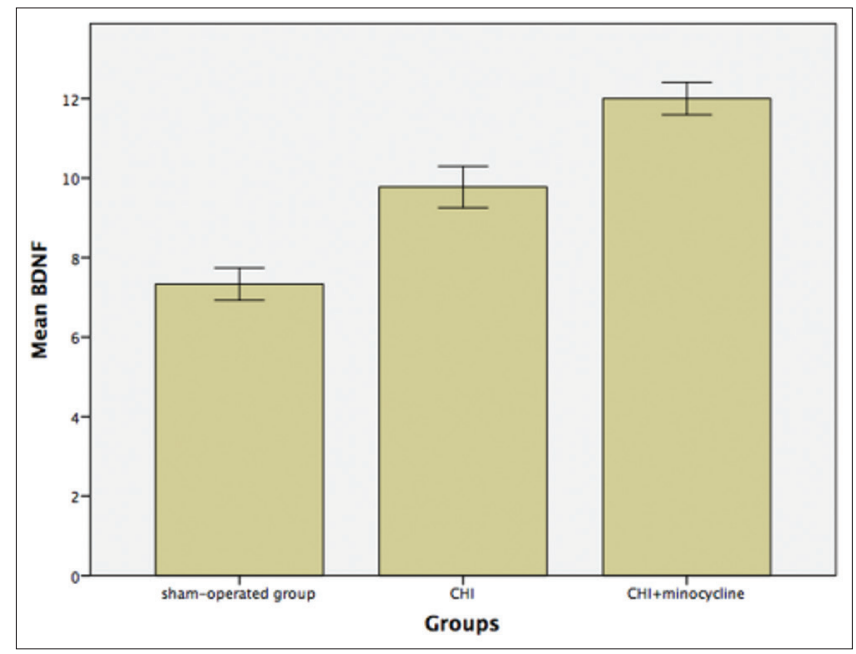

Figure 5: Expression of brain-derived neurotropic factor in brain tissue 5 days after closed head injury 


\section{Minocycline increased the proliferation capacity of NSC}

To assess the proliferation capacity of NSC, we studied the expression of SOX2. Immunohistochemistry showed that the expression of SOX2 was upregulated at 5 days in the $\mathrm{CHI}+$ minocycline group (Mean: 11.67 \pm 1.94 ) (Figure 6). In the sham-operated group, fewer cells stained by SOX2 were seen in the DG as well as in the brain parenchyma. In the $\mathrm{CHI}$ group, the number of cells stained by SOX2 was increased in the DG. The number of cells labeled with SOX2 in the $\mathrm{CHI}+$ minocycline group was significantly increased compared to the sham-operated group and the $\mathrm{CHI}$ group $(p<0.05$; Table 1$)$.

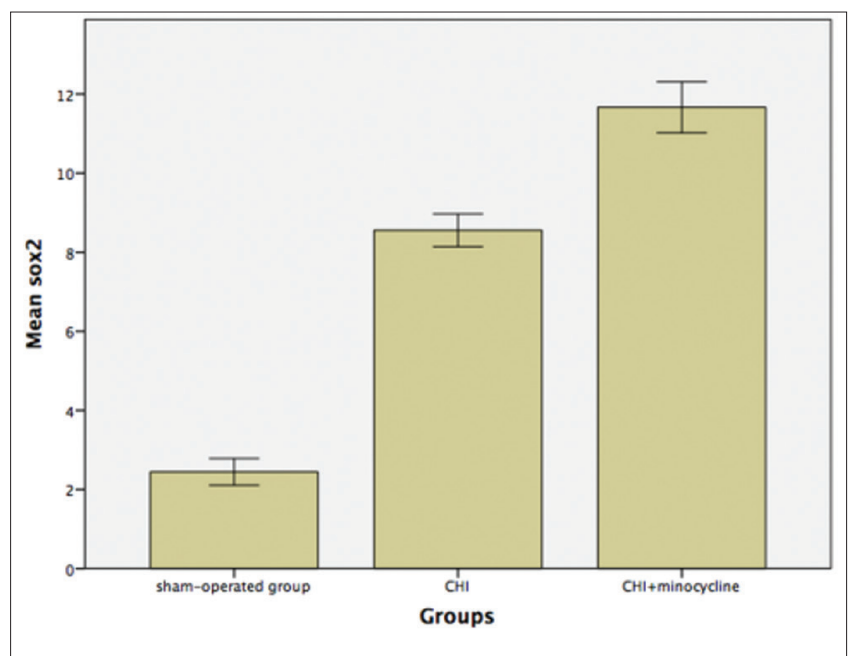

Figure 6: Expression of SOX2 in brain tissue 5 days after closed head injury

\section{Discussion}

We investigated the effects of minocycline, a promising agent for treat TBI in the "acute phase," on endogenous NSCs in vivo using immunohistochemistry. Our data suggest a positive effect of minocycline on NSC proliferation in the SGZ of the DG of the hippocampus.

Minocycline is a second-generation, semi-synthetic tetracycline analog which has antiinflammatory, immunomodulatory, and neuroprotective activities [25], [26]. Minocycline has been studied from a variety of experiments in neurological disorders, including hypoxic-ischemic injury [27], focal ischemia [16], Huntington's disease [28], and amyotrophic lateral sclerosis [29]. Several mechanisms of action have been described to account for this effect, including anti-inflammatory [30] and antiapoptotic properties [31], as well as the inhibition of both polyadenosine diphosphate ribose polymerase- 1 and matrix metalloproteinases [32].

Our finding that minocycline has positive effects on NSC numbers confirms and extends previous findings, suggesting clinically useful properties of minocycline in neural injury therapy since the mobilization of NSCs is associated with better functional recovery from motor deficits [33], with the degree of behavioral recovery correlating with the number of stem cells surviving to reach the target tissue [34].

BDNF and NGF are well-characterized neurotrophins involved in the differentiation and survival of a number of neurons localized in the peripheral and CNS [35]. BDNF has important roles for neuroblast migration, survival, and integration of neurogenesis in the SVZ. The study using mice with a deletion of BDNF following TBI showed an escalation of newborn neuron death. Thus, BDNF plays a critical role in promoting the survival and integration of NSPCderived newborn neuron into neural circuitry [35]. We found that minocycline could significantly upregulate the expression of BDNF in the SGZ of the DG of the hippocampus.

Using immunohistochemistry, we found that NRF-2 was significantly upregulated in the $\mathrm{CHI}$ group compared to the sham-operated group ( $p<0.05$ ). All of this indicated that NRF-2 protein levels in the DG were raised after TBI. The previous research showed that TBI will activate the NRF2/antioxidant response element (ARE) pathway and increase the activity of NRF-2 transcription regulation. However, the regulation only increased the NRF-2 protein level but showed no change in the NRF-2 mRNA level. The NRF2/ARE pathway in TBI has an important neuroprotective role by inhibiting inflammatory cytokines and oxidative stress injuries. Two important antioxidases in the downstream of NRF2/ARE pathway are $\mathrm{HO}-1$ and $\mathrm{NQO} 1$. $\mathrm{HO}-1$ can produce dehydrobilirubin by catalyzing hematoma and decreasing the generation of free radicals. NQO1 can catalyze the reduction of two electrons and degrade quinones and its ramification to prevent participation in the reduction-oxidation reaction [36].

In this study, the NRF-2 level of CHI+minocycline was significantly increased compared to the $\mathrm{CHI}$ group, as was the SOX2 level. These results showed that minocycline administration increased NRF-2 levels after traumatic injury and promoted the proliferation of NSCs. The proliferation of NSCs was proved by an increase in SOX2 levels. SOX2 has an important role for referring the differentiation and maintaining the properties of NSCs [37]. Increased NRF-2 levels will mediate the induction of glutamate-cysteine ligase modifier subunit (GCLM) and enhance binding of AREs in the promoter region of its target genes. These conditions will activate multiple cell survival mechanisms through antioxidant, anti-inflammatory, and other cytoprotective pathways. NRF-2 was reportedly reduced in an intracellular redox state and reactive oxygen species, thus promoting cell proliferation and survival. With its roles, NRF-2 has been related to cell growth, self-renewal, mitosis, and prolonged lifespan, which are definitely associated with NSC functions [38]. 


\section{Conclusion}

This study provided data that minocycline administration increased the expression of NSCs following TBI. To the best of our knowledge, this is the first study to demonstrate the effect of minocycline in TBI. There were two main limitations of this study. First, it did not demonstrate how minocycline could increase stem cell expression, and second, there was no comparison regarding clinical outcome in the animals. Further investigations should be considered. In conclusion, minocycline is a promising candidate in TBI therapy, as it has a direct positive effect on the proliferation of endogenous NSCs in vivo.

\section{References}

1. Gage FH. Mammalian neural stem cells. Science. 2000;287(5457):1433-8.

PMid:10688783

2. Kempermann G, Jessberger S, Steiner B, Kronenberg G. Milestones of neuronal development in the adult hippocampus. Trends Neurosci. 2004;27(8):447-52. https://doi.org/10.1016/j. tins.2004.05.013

PMid:15271491

3. Seki T. Microenvironmental elements supporting adult hippocampal neurogenesis. Anat Sci Int. 2003;78(2):69-78. https://doi.org/10.1046/j.0022-7722.2003.00043.x PMid:12828419

4. Peeters W, van den Brande R, Polinder S, Brazinova A, Steyerberg EW, Lingsma HF, et al. Epidemiology of traumatic brain injury in Europe.Acta Neurochir(Wien). 2015;157(10):168396. https://doi.org/10.1007/s00701-015-2512-7 PMid:26269030

5. Masel BE, DeWitt DS. Traumatic brain injury: A disease process, not an event. J Neurotrauma. 2010;27(8):1529-40. https://doi. org/10.1089/neu.2010.1358

PMid:20504161

6. Werner $\mathrm{C}$, Engelhard K. Pathophysiology of traumatic brain injury. Br J Anaesth. 2007;99(1):4-9.

PMid:17573392

7. Morganti-Kossmann MC, Satgunaseelan L, Bye $N$ Kossmann T. Modulation of immune response by head injury. Injury. 2007;38(12):1392-400. https://doi.org/10.1016/j. injury.2007.10.005

PMid:18048036

8. Ekdahl CT, Claasen JH, Bonde $\mathrm{S}$, Kokaia Z, Lindvall $\mathrm{O}$ Inflammation is detrimental for neurogenesis in adult brain. Proc Natl Acad Sci U S A. 2003;100(23):13632-7. https://doi. org/10.1073/pnas.2234031100

PMid: 14581618

9. Kaur K, Kaur R, Kaur M. Recent advances in Alzheimer's disease: Causes and treatment. Int J Pharm Pharm Sci. 2016;8(2):8-15.

10. Vallières L, Campbell IL, Gage FH, Sawchenko PE. Reduced hippocampal neurogenesis in adult transgenic mice with chronic astrocytic production of interleukin-6. J Neurosci. 2002;22(2):48692. https://doi.org/10.1523/jneurosci.22-02-00486.2002 PMid:11784794
11. Elewa HF, Hilali H, Hess DC, Machado LS, Fagan SC. Minocycline for short-term neuroprotection. Pharmacotherapy. 2006;26(4):515-21. https://doi.org/10.1592/phco.26.4.515 PMid: 16553511

12. Phukan $P$, Bawari $M$, Sengupta M. Promising neuroprotective plants from North-East India. Int J Pharm Pharm Sci. 2015;7(3):28-39.

13. Stirling DP, Khodarahmi K, Liu J, McPhail LT, McBride $\mathrm{CB}$, Steeves JD, et al. Minocycline treatment reduces delayed oligodendrocyte death, attenuates axonal dieback, and improves functional outcome after spinal cord injury. J Neurosci. 2004;24(9):2182-90. https://doi.org/10.1523/ jneurosci.5275-03.2004

PMid:14999069

14. Teng YD, Choi H, Onario RC, Zhu S, Desilets FC, Lan S, et al. Minocycline inhibits contusion-triggered mitochondrial cytochrome $\mathrm{c}$ release and mitigates functional deficits after spinal cord injury. Proc Natl Acad Sci U S A. 2004;101(9):3071-6. https://doi.org/10.1073/pnas.0306239101

PMid:14981254

15. Morimoto $\mathrm{N}$, Shimazawa $\mathrm{M}$, Yamashima $\mathrm{T}$, Nagai $\mathrm{H}$, Hara $\mathrm{H}$ Minocycline inhibits oxidative stress and decreases in vitro and in vivo ischemic neuronal damage. Brain Res. 2005;1044(1):815. https://doi.org/10.1016/j.brainres.2005.02.062 PMid:15862784

16. Xu L, Fagan SC, Waller JL, Edwards D, Borlongan CV, Zheng J et al. Low dose intravenous minocycline is neuroprotective after middle cerebral artery occlusion-reperfusion in rats. BMC Neurol. 2004;4:7. https://doi.org/10.1186/1471-2377-4-7 PMid:15109399

17. Du Y, Ma Z, Lin S, Dodel RC, Gao F, Bales KR, et al. Minocycline prevents nigrostriatal dopaminergic neurodegeneration in the MPTP model of Parkinson's disease. Proc Natl Acad Sci U S A. 2001;98(25):14669-74. https://doi.org/10.1073/ pnas. 251341998

PMid:11724929

18. Siopi E, Cho AH, Homsi S, Croci N, Plotkine M, MarchandLeroux C, et al. Minocycline restores SAPPa levels and reduces the late histopathological consequences of traumatic brain injury in mice. J Neurotrauma. 2011;28(10):2135-43. https://doi. org/10.1089/neu.2010.1738

PMid:21770756

19. Kelso ML, Scheff NN, Scheff SW, Pauly JR. Melatonin and minocycline for combinatorial therapy to improve functional and histopathological deficits following traumatic brain injury. Neurosci Lett. 2011;488(1):60-4. https://doi.org/10.1016/j. neulet.2010.11.003

PMid:21056621

20. Tikka T, Fiebich BL, Goldsteins G, Keinanen R, Koistinaho J. Minocycline, a tetracycline derivative, is neuroprotective against excitotoxicity by inhibiting activation and proliferation of microglia. J Neurosci. 2001;21(8):2580-8. https://doi. org/10.1523/jneurosci.21-08-02580.2001

PMid:11306611

21. Krady JK, Basu A, Allen CM, Xu Y, LaNoue KF, Gardner TW, et al. Minocycline reduces proinflammatory cytokine expression, microglial activation, and caspase- 3 activation in a rodent model of diabetic retinopathy. Diabetes. 2005;54(5):1559-65. https:// doi.org/10.2337/diabetes.54.5.1559 PMid:15855346

22. Seabrook TJ, Jiang L, Maier M, Lemere CA. Minocycline affects microglia activation, abeta deposition, and behavior in APP-tg mice. Glia. 2006;53(7):776-82. https://doi.org/10.1002/ glia.20338

PMid:16534778 
23. Fan LW, Pang $\mathrm{Y}$, Lin S, Tien LT, Ma T, Rhodes PG, et al. Minocycline reduces lipopolysaccharide-induced neurological dysfunction and brain injury in the neonatal rat. J Neurosci Res. 2005;82(1):71-82. https://doi.org/10.1002/jnr.20623

\section{PMid:16118791}

24. Zanjani TM, Sabetkasaei M, Mosaffa N, Manaheji H, Labibi F, Farokhi B. Suppression of interleukin- 6 by minocycline in a rat modelofneuropathicpain. EurJPharmacol.2006;538(1-3):66-72. https://doi.org/10.1016/j.ejphar.2006.03.063

PMid:16687137

25. Brundula V, Rewcastle NB, Metz LM, Bernard CC, Yong VW. Targeting leukocyte MMPs and transmigration: Minocycline as a potential therapy for multiple sclerosis. Brain. 2002;125(Pt6):1297-308. https://doi.org/10.1093/brain/awf133 PMid:12023318

26. Yong VW, Wells J, Giuliani F, Casha S, Power C, Metz LM. The promiseofminocycline in neurology. LancetNeurol.2004;3(12):74451. https://doi.org/10.1016/s1474-4422(04)00937-8 PMid:15556807

27. Arvin KL, Han BH, Du Y, Lin SZ, Paul SM, Holtzman DM. Minocycline markedly protects the neonatal brain against hypoxic-ischemic injury. Ann Neurol. 2002;52(1):54-61. https:// doi.org/10.1002/ana.10242

PMid:12112047

28. Chen M, Ona VO, Li M, Ferrante RJ, Fink KB, Zhu S, et al. Minocycline inhibits caspase- 1 and caspase- 3 expression and delays mortality in a transgenic mouse model of Huntington disease. Nat Med. 2000;6(7):797-801. https://doi. org/10.1038/77528

PMid:10888929

29. Zhu S, Stavrovskaya IG, Drozda M, Kim BY, Ona V, Li M, et al. Minocycline inhibits cytochrome $c$ release and delays progression of amyotrophic lateral sclerosis in mice. Nature. 2002;417(6884):74-8. https://doi.org/10.1038/417074a PMid:11986668

30. Wixey JA, Reinebrant HE, Spencer SJ, Buller KM. Efficacy of post-insult minocycline administration to alter long-term hypoxia-ischemia-induced damage to the serotonergic system in the immature rat brain. Neuroscience. 2011;182:184-92. https://doi.org/10.1016/j.neuroscience.2011.03.033

PMid:21440046
31. Wang J, Wei Q, Wang CY, Hill WD, Hess DC, Dong Z. Minocycline up-regulates $\mathrm{Bcl}-2$ and protects against cell death in mitochondria. J Biol Chem. 2004;279(9):19948-54. https:// doi.org/10.1074/jbc.m313629200

PMid:15004018

32. Alano CC, Kauppinen TM, Valls AV, Swanson RA. Minocycline inhibits poly (ADP-ribose) polymerase-1 at nanomolar concentrations. Proc Natl Acad Sci U S A. 2006;103(25):968590. https://doi.org/10.1073/pnas.0600554103

PMid:16769901

33. Androutsellis-Theotokis A, Leker RR, Soldner F, Hoeppner DJ, Ravin R, Poser SW, et al. Notch signalling regulates stem cell numbers in vitro and in vivo. Nature. 2006;442(7104):823-6. https://doi.org/10.1038/nature04940 PMid:16799564

34. Guzman R, De Los Angeles A, Cheshier S, Choi R, Hoang S, Liauw $\mathrm{J}$, et al. Intracarotid injection of fluorescence activated cell-sorted CD49d-positive neural stem cells improves targeted cell delivery and behavior after stroke in a mouse stroke model. Stroke. 2008;39(4):1300-6. https://doi.org/10.1161/ strokeaha.107.500470

PMid:18309158

35. Nomoto H, Takaiwa M, Mouri A, Furukawa S. Pro-region of neurotrophins determines the processing efficiency. Biochem Biophys Res Commun. 2007;356(4):919-24. https://doi. org/10.1016/j.bbrc.2007.03.059

PMid:17395157

36. Cheng ZG, Zhang GD, Shi PQ, Du BS. Expression and antioxidation of Nrf2/ARE pathway in traumatic brain injury. Asian Pac J Trop Med. 2013;6(4):305-10. PMid:23608333

37. Zhang S, Cui W. Sox2, a key factor in the regulation of pluripotency and neural differentiation. World J Stem Cells. 2014;6(3):305-11. https://doi.org/10.4252/wjsc.v6.i3.305 PMid:25126380

38. Corenblum MJ, Ray S, Remley QW, Long M, Harder B, Zhang DD, et al. Reduced Nrf2 expression mediates the decline in neural stem cell function during a critical middle-age period. Aging Cell. 2016;15(4):725-36. https://doi.org/10.1111/ acel. 12482

PMid:27095375 